\title{
Synaptic Calcium Regulation in Hair Cells of the Chicken Basilar Papilla
}

\author{
Gi Jung Im, Howard S. Moskowitz, Mohammed Lehar, Hakim Hiel, and $@$ Paul Albert Fuchs \\ The Center for Hearing and Balance, Department of Otolaryngology-Head and Neck Surgery, and the Center for Sensory Biology, the Institute for Basic \\ Biomedical Sciences, Johns Hopkins University School of Medicine, Baltimore, Maryland 21205
}

Cholinergic inhibition of hair cells occurs by activation of calcium-dependent potassium channels. A near-membrane postsynaptic cistern has been proposed to serve as a store from which calcium is released to supplement influx through the ionotropic ACh receptor. However, the time and voltage dependence of acetylcholine (ACh)-evoked potassium currents reveal a more complex relationship between calcium entry and release from stores. The present work uses voltage steps to regulate calcium influx during the application of ACh to hair cells in the chicken basilar papilla. When calcium influx was terminated at positive membrane potential, the ACh-evoked potassium current decayed exponentially over $\sim 100 \mathrm{~ms}$. However, at negative membrane potentials, this current exhibited a secondary rise in amplitude that could be eliminated by dihydropyridine block of the voltage-gated calcium channels of the hair cell. Calcium entering through voltage-gated channels may transit through the postsynaptic cistern, since ryanodine and sarcoendoplasmic reticulum calcium-ATPase blockers altered the time course and magnitude of this secondary, voltage-dependent contribution to ACh-evoked potassium current. Serial section electron microscopy showed that efferent and afferent synaptic structures are juxtaposed, supporting the possibility that voltage-gated influx at afferent ribbon synapses influences calcium homeostasis during long-lasting cholinergic inhibition. In contrast, spontaneous postsynaptic currents ("minis") resulting from stochastic efferent release of ACh were made briefer by ryanodine, supporting the hypothesis that the synaptic cistern serves primarily as a calcium barrier and sink during low-level synaptic activity. Hypolemmal cisterns such as that at the efferent synapse of the hair cell can play a dynamic role in segregating near-membrane calcium for short-term and long-term signaling.

Key words: acetylcholine; calcium store; cochlea; efferent inhibition; hair cell; synaptic cistern

\section{Introduction}

Cholinergic inhibition of hair cells results when calcium influx through the ionotropic acetylcholine receptor (AChR) activates nearby calcium-dependent potassium channels to hyperpolarize the membrane (Flock and Russell, 1973; Art et al., 1982; Fuchs and Murrow, 1992a; Sugai et al., 1992; Kakehata et al., 1993; Ohmori, 1993; Blanchet et al., 1996; Dulon and Lenoir, 1996; Evans, 1996; Nenov et al., 1996). As a result, acoustic receptor potentials are shunted, transmitter release is reduced, and activity in associated afferent neurons is suppressed (Wiederhold and Kiang, 1970; Art and Fettiplace, 1984; Winslow and Sachs, 1987). While these functional attributes and the underlying membrane

\footnotetext{
Received June 26, 2014; revised Sept. 26, 2014; accepted 0ct. 30, 2014.

Author contributions: P.A.F. designed research; G.J.I., H.S.M., M.L., H.H., and P.A.F. performed research; G.J.I., H.S.M., and P.A.F. analyzed data; G.J.I., H.S.M., and P.A.F. wrote the paper.

This research was supported by National Institute on Deafness and Other Communication Disorders Grants R01DC001508 and P30 DC005211, a National Research Foundation of Korea funded by the Korean Government Ministry of Education, Science and Technology Basic Research Promotion Fund Grant NRF-2010-013-E00015 to G.J.I. The authors declare no competing financial interests.

Correspondence should be addressed to Paul A. Fuchs, 818 Ross Research Building, the Johns Hopkins University School of Medicine, 720 Rutland Avenue, Baltimore, MD 21205. E-mail: pfuchs1@jhmi.edu.

G.J. Im's present address: Department of Otolaryngology, Korea University, Seoul 136-705, Republic of Korea.

H.S. Moskowitz's present address: Department of Otorhinolaryngology-Head and Neck Surgery, Albert Einstein College of Medicine/Montefiore Medical Center, Bronx, NY 10467.

DOI:10.1523/JNEUROSCI.2615-14.2014

Copyright $\odot 2014$ the authors $\quad 0270-6474 / 14 / 3416688-10 \$ 15.00 / 0$
}

conductances (Fuchs and Murrow, 1992a,b; Elgoyhen et al., 1994, 2001; Dulon et al., 1998; Oliver et al., 2000; Matthews et al., 2005) have been well characterized, the characteristics of the cytoplasmic calcium signal that drives inhibition are less certain. In particular, pharmacological and imaging studies suggest that internal calcium stores also contribute, or even may be required (Shigemoto and Ohmori, 1991; Sridhar et al., 1997; Evans et al., 2000; Lioudyno et al., 2004). This hypothesis is motivated in part by an obligatory postsynaptic structure found in hair cells, a nearmembrane cistern that aligns with the efferent terminal (Smith and Sjöstrand, 1961; Gulley and Reese, 1977; Saito, 1980; Fuchs et al., 2014). At a minimum, the cistern defines a tightly restricted diffusion space for entering calcium, but also has been nominated as a store for calcium-induced calcium release, at least during prolonged exposure to exogenous ACh.

The distinction of calcium influx versus release from stores has been confounded in part by the resolution and time course of cellular experiments. Thus, early efforts on isolated hair cells studied membrane currents or calcium signals lasting many seconds upon acetylcholine application (Shigemoto and Ohmori, 1990; Dallos et al., 1997). Subsequent work showed that such long-lasting signals reflect global calcium extending far beyond the synaptic region (Evans et al., 2000). In contrast, quantal release of ACh activates hair cell SK channels for $<100$ ms during synaptic transmission (Oliver et al., 2000). Like- 
A

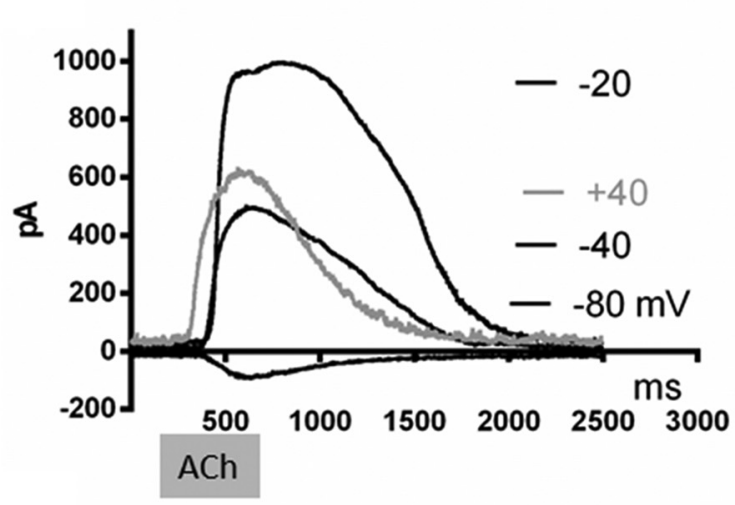

C

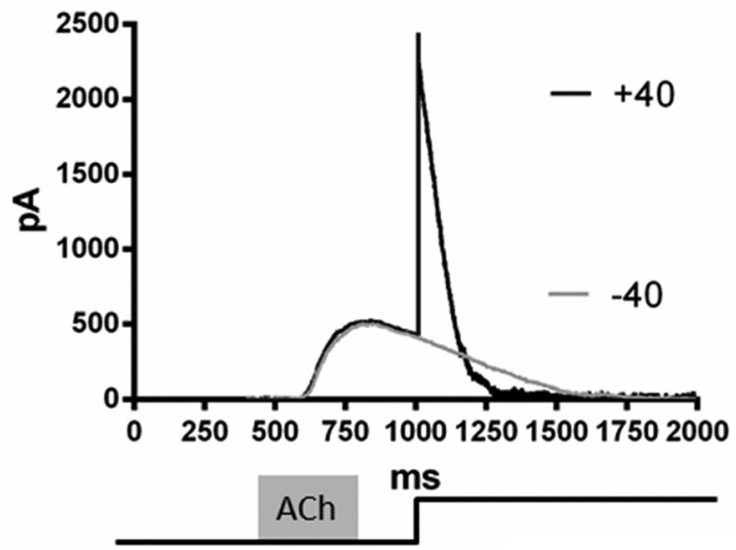

B

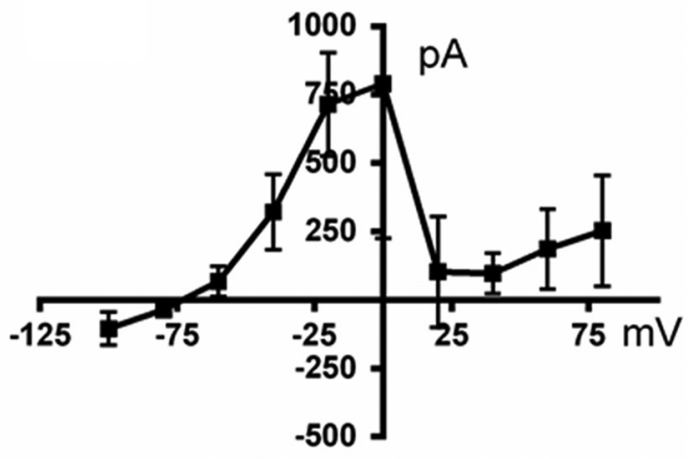

D

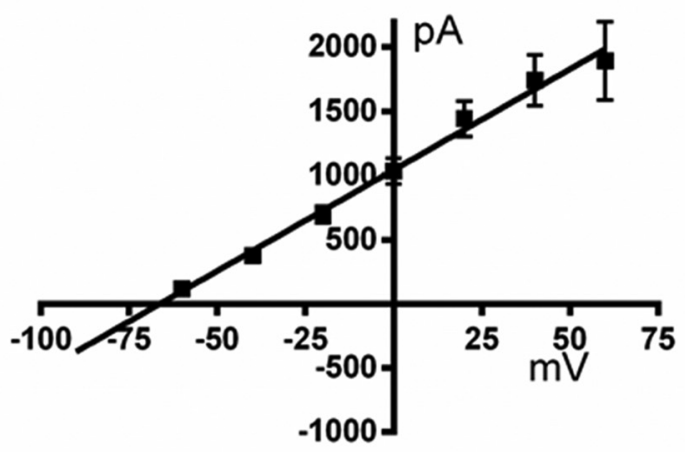

Figure 1. Voltage dependence of ACh-evoked membrane current. $A, A C h$-evoked current at membrane potentials of $-80 \mathrm{mV}$ (inward), $-40 \mathrm{mV}$ (outward, delayed rise), $-20 \mathrm{mV}$ (largest peak), and $+40 \mathrm{mV}$ (gray trace, early rise). Chicken short hair cells have a very small steady-state current at $-40 \mathrm{mV}$ (holding potential), so no subtraction was used for this figure. $\boldsymbol{B}$, Peak ACh-evoked current as a function of steady-state membrane potential (voltage changed before ACh application). Values are the average of currents from seven cells. $\boldsymbol{C}$, ACh-evoked membrane current initiated at $-40 \mathrm{mV}$, with a delayed voltage step to elicit tail currents at $+40 \mathrm{mV}$. The application time of ACh is indicated by gray boxes. $D$, Initial (peak) membrane current during the step. Values are the average from seven cells.

wise, the voltage dependence of ACh-evoked potassium currents is consistent with a direct requirement for calcium entry, rather than secondary release from stores (Martin and Fuchs, 1992).

Thus, the role of postsynaptic calcium stores may depend on the time course over which cholinergic activity occurs. In addition, the extent to which internal stores are calcium loaded may be determinant (Evans et al., 2000). In the present study, membrane voltage was used to alter the timing and extent of calcium entry, as signaled by calcium-dependent potassium current in hair cells of the basilar papilla (auditory organ) of the embryonic chicken. Potassium "tail currents" at positive membrane potential (where calcium influx was reduced) decayed exponentially to zero, as though dependent only on calcium influx. However, between -40 and $0 \mathrm{mV}$, calcium entry through voltage-gated channels could contribute to cholinergic activation of SK channels over the course of hundreds of milliseconds. This interaction was sensitive to ryanodine and inhibitors of endoplasmic calcium pumps, presumably affecting the postsynaptic cistern. These results demonstrate that the synaptic cistern is not a calcium store in the traditional sense. Rather, it serves as a dynamic buffer to restrict synaptic calcium signals to their functional domains. In hair cells, this segregates the activity of juxtaposed efferent and afferent synapses.

\section{Materials and Methods}

Preparation of tissue and solutions. All experimental protocols were performed in accordance with National Institutes of Health Guide for the Care and Use of Laboratory Animals. Animal protocols were approved by the Johns Hopkins University Animal Care and Use Committee. The auditory organ (basilar papilla) was dissected from the temporal bone of embryonic chickens (white Leghorns either sex, 17-20 d in ovo). After 5-10 $\mathrm{min}$ of exposure to protease (type XXIV, $0.1 \mathrm{mg} / \mathrm{ml}$; SigmaAldrich) in buffered saline, the tegmentum vasculosum and tectorial membrane were removed, exposing the sensory hair cells. Furrows were dug across the papilla by removing strips of hair cells using mouth suction with a cleaning pipette. This improved access to the basolateral surfaces of more hair cells. The basilar papilla was secured to a coverslip by small spring clips (made from fine insect pins) and transferred to a recording chamber on the stage of an upright microscope (Axioskop II equipped with Nomarski optics, Zeiss). For some experiments, proteolysis was avoided so that the tectorial membrane could be stripped from the basilar papilla with most of the short hair cells (SHCs) still attached. This "tectorial preparation" was then inverted and secured in the recording chamber by spring clips, or placement onto poly-lysinecoated coverslips.

Voltage-clamp recording. Whole-cell, tight-seal voltage-clamp recordings were made with $1 \mathrm{~mm}$ borosilicate glass micropipettes (WPI) ranging from 4 to $6 \mathrm{M} \Omega$ resistance. Short hair cells were recorded in a region $25-50 \%$ the distance from the apical (lagenar) to the basal tip of the basilar papilla of the chicken. Cells were visualized through a $40 \times$ water- 
A

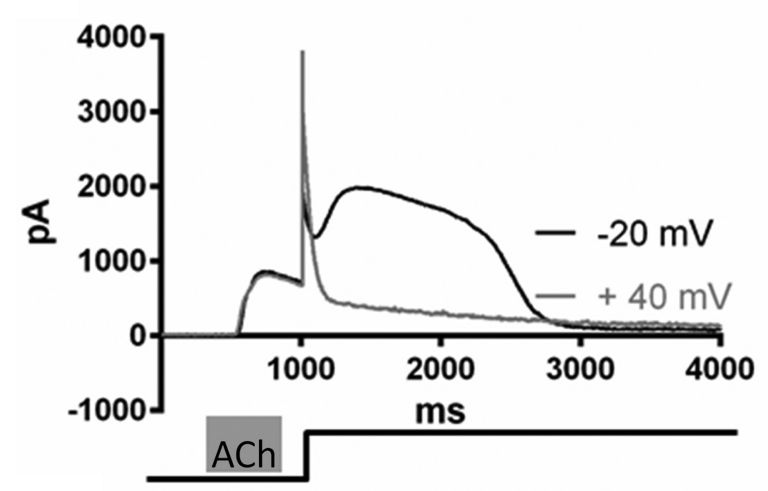

C

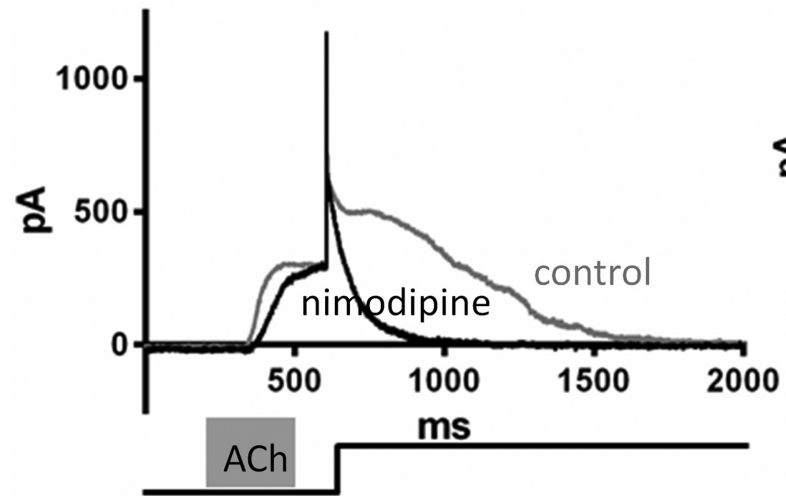

B

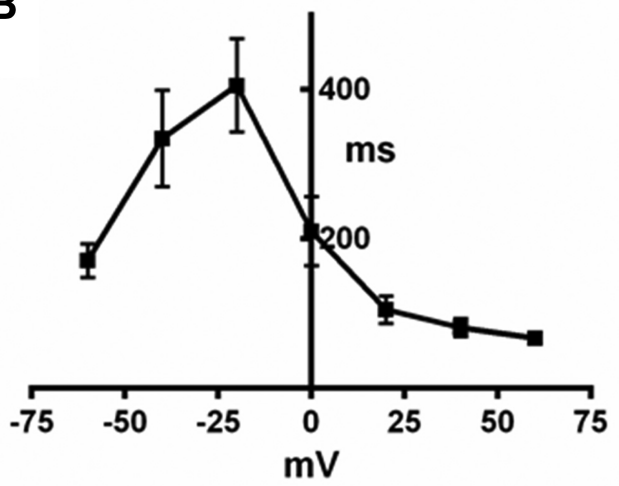

D

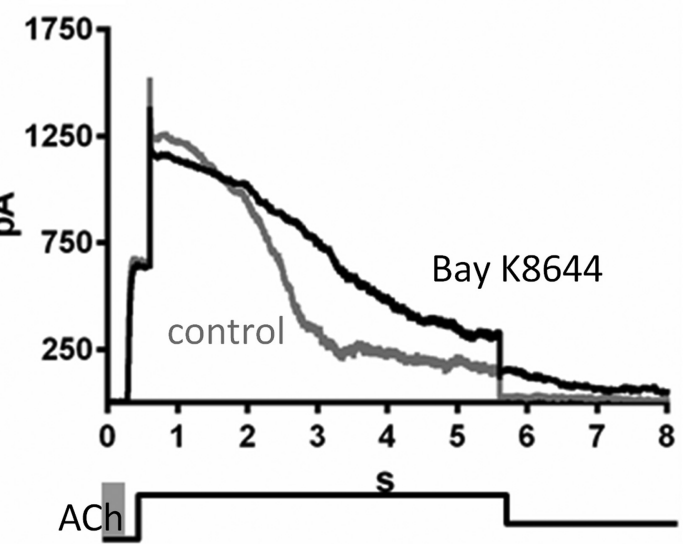

Figure 2. Voltage-gated calcium channels extend the ACh-evoked current. $A, A C h$-evoked currents at -20 and $+40 \mathrm{mV}$. Note that the tail current at $+40 \mathrm{mV}$ declines exponentially, while that at $-20 \mathrm{mV}$ rebounds to rise slowly after the voltage step begins. $\boldsymbol{B}$, Duration at half-amplitude for voltage steps from -40 to $+60 \mathrm{mV}$; values are averages for 10 cells. $\boldsymbol{C}$, A voltage step to -20 $\mathrm{mV}$ produces a prolonged tail current for the $\mathrm{ACh}$ response initiated at $-40 \mathrm{mV}$ (control, gray trace). Exposure to $10 \mu \mathrm{m}$ nimodipine eliminated the delayed component, leaving an exponentially decaying tail current (nimodipine, black trace). D, Exposure to the L-type agonist Bay K8644 increased the ACh-evoked tail current at - $20 \mathrm{mV}$ in some cells (black trace, Bay K8644; gray trace, control). The application time of ACh is indicated by gray boxes.

immersion objective and confirmed to be short hair cells by their position far from the neural limbus, where they receive predominantly efferent innervation (Zidanic, 2002). Furthermore, the voltagedependent membrane conductance was dominated by short hair, cellspecific, "A-type," rapidly inactivating potassium currents (Murrow and Fuchs, 1990). Finally, these cells responded to ACh with a combination of ligand-gated cation current followed by $\mathrm{Ca}^{2+}$-dependent potassium current through apamin-sensitive ("SK-like") potassium channels, as demonstrated previously (Fuchs and Murrow, 1992a). Patch and puffer pipettes (3-5 M $\Omega$ ) were mounted on piezoelectric manipulators (ROE200, Sutter Instruments) for positioning on hair cells. Voltage-clamp recordings were obtained using an Axopatch 200B running under Clampex software (Molecular Devices). Subsequent data analysis was performed with Clampfit, Excel, Origin, and MiniAnalysis (Synaptosoft) software. Recordings were made at room temperature. ACh $(100 \mu \mathrm{M})$ was pressure ejected (Picospritzer; General Valve Corporation) for 100 $300 \mathrm{~ms}$ from a nearby "puffer" pipette ( $\sim 1 \mu \mathrm{m}$ opening), resulting in ACh-evoked currents of variable waveforms, depending on the positioning and movement of the cell, but usually lasting $0.5-1 \mathrm{~s}$.

Bath solutions were exchanged by gravity feed and suction drain. Unless effects were immediately obvious (i.e., nimodipine), experimental drugs remained in the bath 3-5 min before data were collected. The standard external saline contained the following (in $\mathrm{mm}$ ): $\mathrm{NaCl}, 144$; $\mathrm{KCl}, 5.8 ; \mathrm{MgCl}_{2}, 0.9 ; \mathrm{CaCl}_{2}, 1.3 ; \mathrm{NaH}_{2} \mathrm{PO}_{4}, 0.7 ;$ HEPES, 10; D-glucose 5.6, adjusted to $\mathrm{pH} 7.4$ with $\mathrm{NaOH}$. The osmolarity was adjusted to $300 \sim 320$ mOsM with the predominant salt. The recording pipette contained the following (in mM): $135 \mathrm{KCl}, 3.5 \mathrm{MgCl}_{2}, 0.1 \mathrm{CaCl}_{2}, 5$ EGTA, 5 HEPES and $2.5 \mathrm{Na}_{2} \mathrm{ATP}$, titrated to $\mathrm{pH} 7.2$ with $\mathrm{KOH}$, and osmolarity was adjusted to
295 mOsM. Membrane potentials are reported disregarding the junction potential of $-4 \mathrm{mV}$ with $\mathrm{KCl}$ internal solution.

Electron microscopy. The temporal bone from embryonic chickens (days 20-21 in ovo) was perfused through the oval window with $1 \%$ osmium $\left(\mathrm{OsO}_{4}\right)$ and $1 \%$ potassium ferricyanide $\left[\mathrm{FeK}_{3}(\mathrm{CN})_{6}\right]$ in $0.1 \mathrm{M}$ sym-collidine- $\mathrm{HCl}$ solution, $\mathrm{pH}$ 7.4. The tissue was post-fixed for $1 \mathrm{~h}$ then rinsed thoroughly in $0.1 \mathrm{~m}$ maleate buffer, $\mathrm{pH}$ 7.4. The basilar papilla was dissected free, and cut into proximal and distal halves. The tissue samples were then processed for embedding into Araldite following standard protocols for transmission electron microscopy. The basilar papillae halves were oriented into Araldite blocks to achieve ultrathin sectioning (Ultracut S, Leica) perpendicular to the tonotopic axis at the midpoint of the basilar papilla. Serial $65 \mathrm{~nm}$ sections were collected onto Formvar-coated slot grids, examined, and photographed on a Hitachi $\mathrm{H} 7600$ transmission electron microscope at $80 \mathrm{kV}$. Efferent contacts were identified, followed, and photographed in consecutive serial sections. Digital images $(2120 \times 2120$ pixels $)$ were collected at 8 or 16 bit depth and analyzed as 8 bit files.

Image analysis. Electron micrographs were collected for analysis at 30,000-fold magnification. Lower-power images were collected for reconstruction of the entire papillar cross section to identify each targeted hair cell and its position across the papillar width. Digital images were imported into Reconstruct software (Fiala, 2005) where montages were assembled, and serial sections calibrated and aligned. Line tracings were made of the plasma membranes of hair cells and neuronal contacts. The synaptic cistern was drawn as an enclosed area, as was the region of cytoplasm between the cistern and the plasma membrane (the cytoplasmic gap). Hair cell ribbons and associated vesicles were traced when 

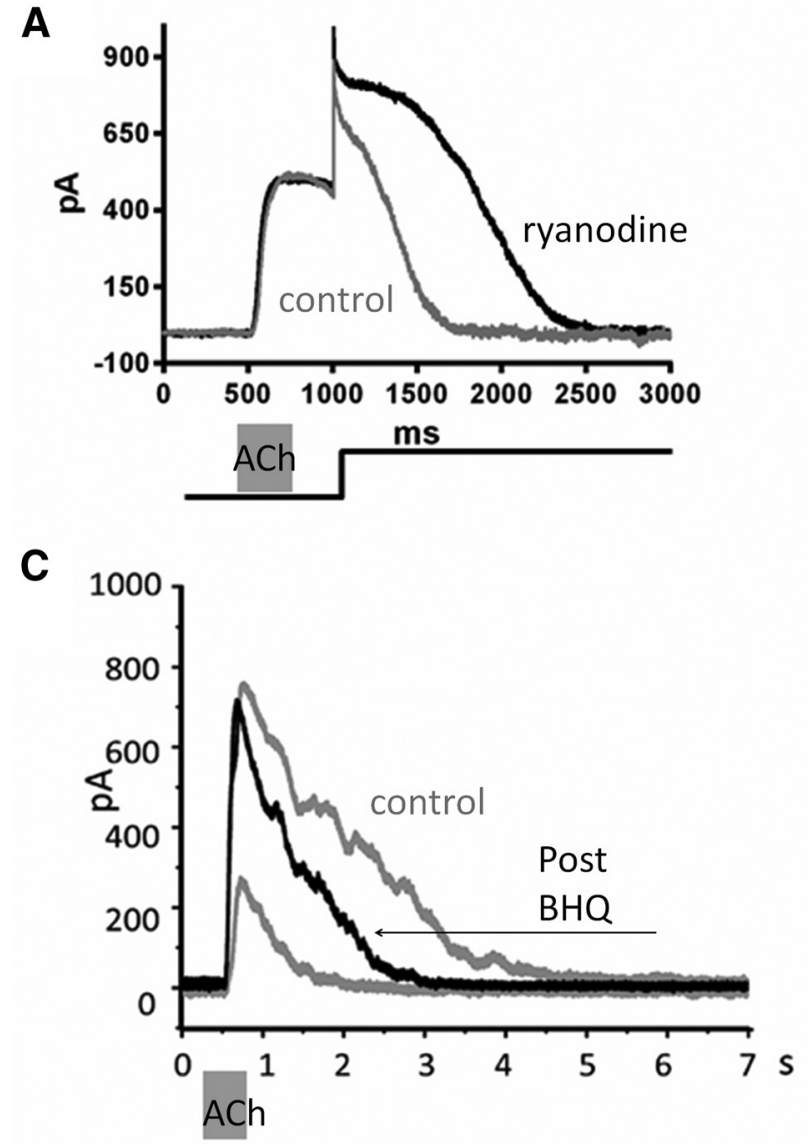

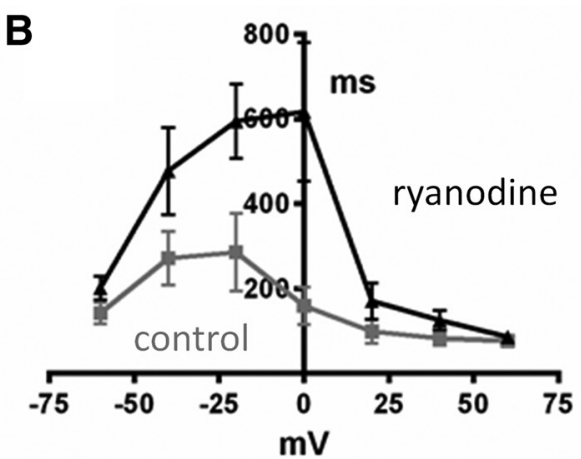

D

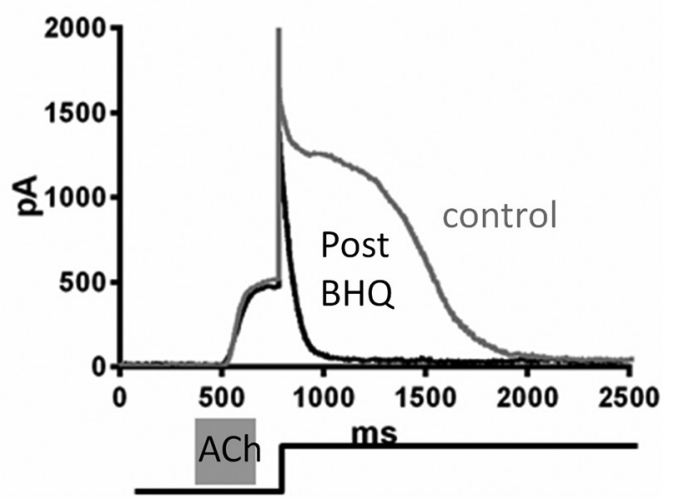

Figure 3. Contribution of calcium stores. $\boldsymbol{A}$, Effect of $1 \mu \mathrm{m}$ ryanodine (black trace) on ACh-evoked tail current at $-20 \mathrm{mV}$ (gray trace is the control). $\boldsymbol{B}$, Average half-amplitude duration of $A C h$-evoked tail current as a function of membrane potential in six cells. Black line shows the effect of $1 \mu$ m ryanodine on half-amplitude duration in the same cells. $C$, The effect of SERCA blocker $t$-BHQ on $A C h$-evoked currents at $-40 \mathrm{mV}$. Gray traces show the initial control and the presence of $t$ - $B H Q$ (lowest amplitude). Black trace shows the recovery of amplitude but not duration after $t$-BHQ administration. $D$, Recovery of the peak current after $t$-BHQ administration (note the identical amplitude at $-40 \mathrm{mV}$, before the voltage step to $0 \mathrm{mV}$ ) but sustained abbreviation of $A C h$-evoked tail current at $0 \mathrm{mV}$ (black trace, gray trace is control). Gray boxes show the time of ACh application.

present in the high-magnification images. The volumes of the synaptic cistern and cytoplasmic gap were computed based on a nominal section thickness of $65 \mathrm{~nm}$. The appositional areas of the efferent terminal and synaptic cistern were obtained by tracing a line along their maximum extent in each section, multiplying by the section thickness, then summing for all sections in the series. This $z$-axis area was divided into the computed volume to obtain the average width of the cisternal lumen and that of the underlying cytoplasmic gap.

Statistical analyses. Results are presented as the mean \pm SD. Statistical significance was evaluated using the Student's $t$ test (two-tailed, unpaired samples) or ANOVA, as appropriate. The $p$ values are reported where significant.

\section{Results}

Voltage dependence of ACh-evoked membrane current

Puffer application of ACh $(100 \mu \mathrm{M}, 300 \mathrm{~ms})$ to chicken SHCs evokes a combined current that flows through cation-selective AChRs, followed by that through calcium-dependent SK potassium channels (Fig. 1A). Consequently, the steady-state currentvoltage relation of the ACh-evoked current is $\mathrm{N}$ shaped (Fuchs and Murrow, 1992a), reflecting the driving forces on sodium, potassium, and calcium (Fig. $1 B$ ). Because the AChR conductance is sharply rectified (McNiven et al., 1996; Lipovsek et al., 2012), the SK current dominates the response at negative membrane potentials and ACh-evoked current reverses near the potassium equilibrium potential. As the membrane is depolarized toward $0 \mathrm{mV}$, the potassium driving force, and so the SK current, increases in amplitude. However, positive to $0 \mathrm{mV}$, the lower driving force on calcium entry through the AChR causes a steep decline in calcium-activated SK currents. Positive to $+40 \mathrm{mV}$, the net membrane current grows again due to the efflux of potassium through the AChR, but no longer includes current through SK channels.

Since the membrane potential was changed before ACh application, these effects show that calcium entry into the hair cell is required to at least initiate the SK current. However, this leaves the possibility that the SK current is sustained after its initiation by cytoplasmic sources of calcium, as with sarcoplasmic release of calcium during muscular contraction. To test this possibility, membrane potential was altered midway through an AChevoked SK current initiated at $-40 \mathrm{mV}$ (Fig. 1C) producing tail currents by analogy to those used to analyze the closure of voltage-gated channels. The instantaneous current just after the transition varied linearly with voltage (Fig. $1 D)$, consistent with the effect of driving force on a current through already open SK channels. For steps to positive membrane potentials, the initially large outward current then decayed exponentially (Fig. 1C). This monotonic decay at positive membrane potential suggests that calcium entry is required to sustain, as well as to initiate, the ACh-evoked SK current. The SK tail current decayed progres- 
sively faster at more positive membrane potential (average decay time constant in 11 cells was $194 \pm 162 \mathrm{~ms}$ at $+20 \mathrm{mV}$, $135 \pm 93 \mathrm{~ms}$ at $+40 \mathrm{mV}$, and $101 \pm 33 \mathrm{~ms}$ at $+60 \mathrm{mV}$ ), reflecting the balance between the declining rate of calcium entry and the presumably constant removal processes. Thus, ACh-evoked SK current at positive membrane potentials appears to depend principally on calcium entry for its maintenance as well as its initiation. However, this conclusion requires some elaboration to account for other aspects of the ACh-evoked current.

\section{Contribution of voltage-gated calcium channels}

While the ACh-evoked SK current declined monotonically at membrane potentials positive to $+20 \mathrm{mV}$, more complex waveforms occurred at less positive membrane potentials. In particular, tail currents at or negative to $0 \mathrm{mV}$ could have a prolonged, multiphasic time course. An initially exponential decay was followed by slower changes, often including a clearly defined rebound in outward current (Fig. $2 A$ ) that peaked 100-300 ms after the start of the voltage step in different cells. To accommodate this waveform variability, the half-amplitude width was used to describe the average time course of the tail current at different membrane potentials (Fig. $2 B$ ). The halfamplitude duration increased from -60 to $-20 \mathrm{mV}$, then decreased for more positive membrane potentials.

These more complex tail currents do not accord with a singular reliance on calcium entry through the AChR, but rather suggest that other sources of calcium can contribute to SK activation. In particular, chicken hair cells express L-type, dihydropyridinesensitive voltage-gated channels that provide calcium influx in the voltage range from -40 to $0 \mathrm{mV}$ (Fuchs et al., 1990; Zidanic and Fuchs, 1995; Martinez-Dunst et al., 1997; Lee et al., 2007), where the longest lasting ACh responses were observed. Application of the L-type calcium channel antagonist nimodipine (10 $\mu \mathrm{M})$ reduced the duration of ACh-evoked SK tail currents to one-third the control value at $-20 \mathrm{mV}(32 \pm 26 \%, n=7$; Fig. $2 C$ ). (The rising phase of the ACh-evoked current showed some variability, depending on the position of the puffer pipette. There was no consistent effect of nimodipine on activation.) The residual tail currents at $-20 \mathrm{mV}$ in the presence of nimodipine decayed exponentially with an average time constant of $71 \pm 29 \mathrm{~ms}$ $(n=7)$. The dihydropyridine activator Bay K8644 caused a smaller, nonsignificant increase in the duration of the AChevoked SK current at $-20 \mathrm{mV}(154 \pm 59 \%, n=6$; Fig. $2 D)$.

These experiments support the hypothesis that calcium influx through voltage-gated L-type channels can contribute to cholinergic activation of SK channels. Of note, this interaction differs from the direct activation of SK channels by voltage-gated influx as described previously in other hair cells (Tucker and Fettiplace, 1996; Marcotti et al., 2004; Kong et al., 2008). In those cases, sustained depolarization itself caused a gradual rise in SK current as cytoplasmic calcium accumulated, whereas, in the present experiment SK activation required ACh receptor gating even with continued depolarization (Figs. 1, 2, 3). This difference could result from various causes, such as the much smaller voltage-gated calcium currents present in chicken short hair cells (Martinez-
Dunst et al., 1997), or the amount of fixed and mobile buffers relative to influx could vary between hair cell types, influencing the ability of cytoplasmic calcium to activate SK channels. To examine this latter possibility in chicken short hair cells, additional recordings were made with reduced calcium buffering (10fold lower EGTA, $0.5 \mathrm{~mm}$ ). Voltage-gated outward current in short hair cells flows through a combination of rapidly activating (BK) and inactivating (A-type) channels (Murrow, 1994; Tan et al., 2013). In contrast, SK current activates and deactivates much more slowly. With $5 \mathrm{~mm}$ cytoplasmic EGTA, voltage steps between -20 and $0 \mathrm{mV}$ produced no sustained outward current (Figs. 1, 2, 3). However, in 7 of 11 short hair cells buffered with 0.5 mM EGTA, a small, slowly rising (delayed $>50 \mathrm{~ms}$ ) SK-like current was observed during a voltage step to $-10 \mathrm{mV}$, reaching an average value of $46 \pm 37 \mathrm{pA}(n=7) 250 \mathrm{~ms}$ after the start of the depolarization. Four other short hair cells buffered with 0.5 mM EGTA had no slowly rising SK-like current during these prolonged ( $500 \mathrm{~ms}$ ) steps to $-10 \mathrm{mV}$.

Thus, even with reduced cytoplasmic buffering, voltage-gated calcium influx into chicken short hair cells has limited direct access to SK channels, implying that a functional barrier segregates cholinergic gating of calcium entry from that of the cytoplasm in general. One possibility is that the synaptic cistern acts as that barrier, both by restricted diffusion and by active uptake of cytoplasmic calcium. However, if the cistern is fully loaded, as by voltage-gated influx, then calcium-induced calcium release could supplement the activation of SK channels to produce enhanced cholinergic responses. This possibility of calcium-induced calcium release was tested using ryanodine to alter calcium-triggered calcium channels in endoplasmic stores, and by inhibiting the sarcoendoplasmic reticulum calcium-ATPase (SERCA) that transports calcium into cytoplasmic stores.

\section{Calcium stores and the response to $\mathrm{ACh}$}

The following experiments address the question of whether cytoplasmic calcium stores contribute to the cholinergic gating of SK channels. Ryanodine was used to alter calcium-induced calcium release, and the SERCA pump inhibitor tert-benzo hydroquinone $(t$-BHQ) was used to "unload" calcium stores by reducing the endoplasmic uptake of calcium. 

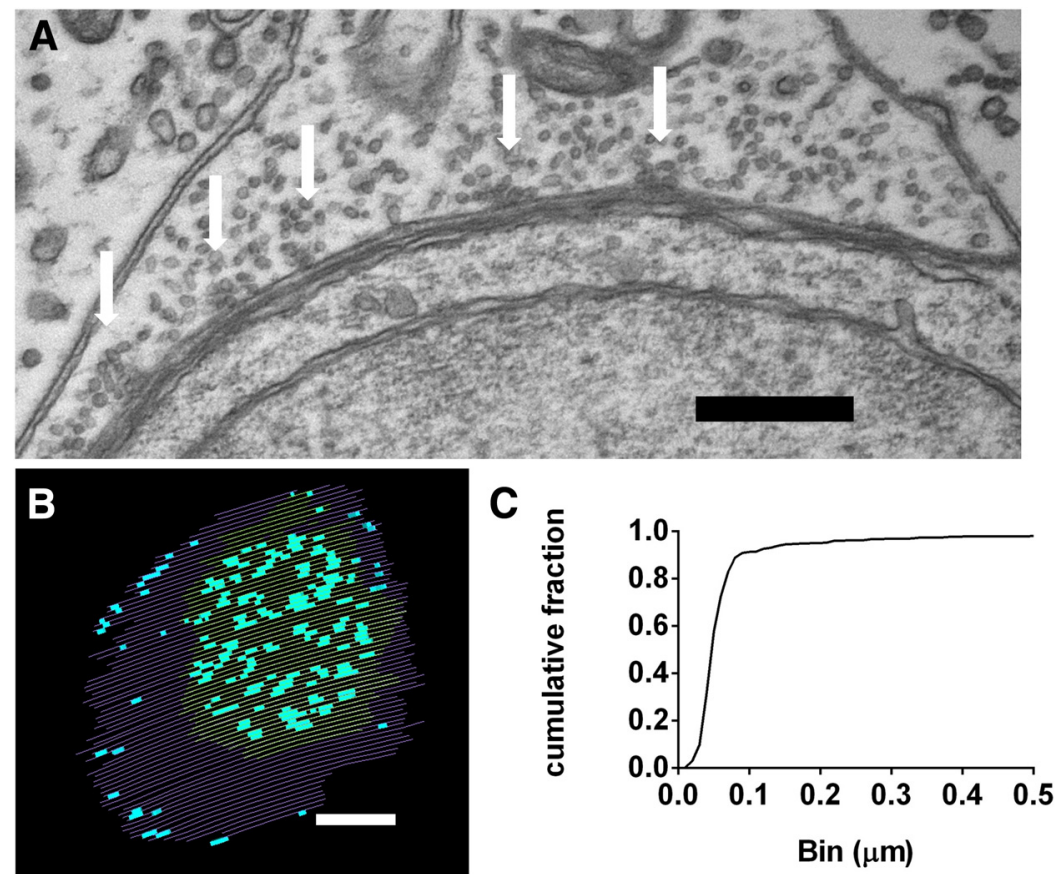

Figure 5. Active zones in the efferent terminal. $\boldsymbol{A}$, Cross section of an efferent terminal showing clusters of vesicles identified as active zones for transmitter release (white arrows). $\boldsymbol{B}$, The $z$-axis projection of 71 sections like that in $\boldsymbol{A}$, tilted forward $\sim 90^{\circ}$ from the plane of the section. Purple lines mark the extent of the efferent contact, dull green lines the location of the synaptic cistern, and turquoise bars the positions of putative active zones. Scale bars, $500 \mathrm{~nm}$. C, Cumulative fraction plot of active zone to cistern distance (517 active zones from efferent synapses on nine hair cells). Each vesicle cluster was demarcated with a line along the plasma membrane (shown as turquoise bars in $\boldsymbol{B}$ ) and with the distance found to the nearest edge of a cistern.

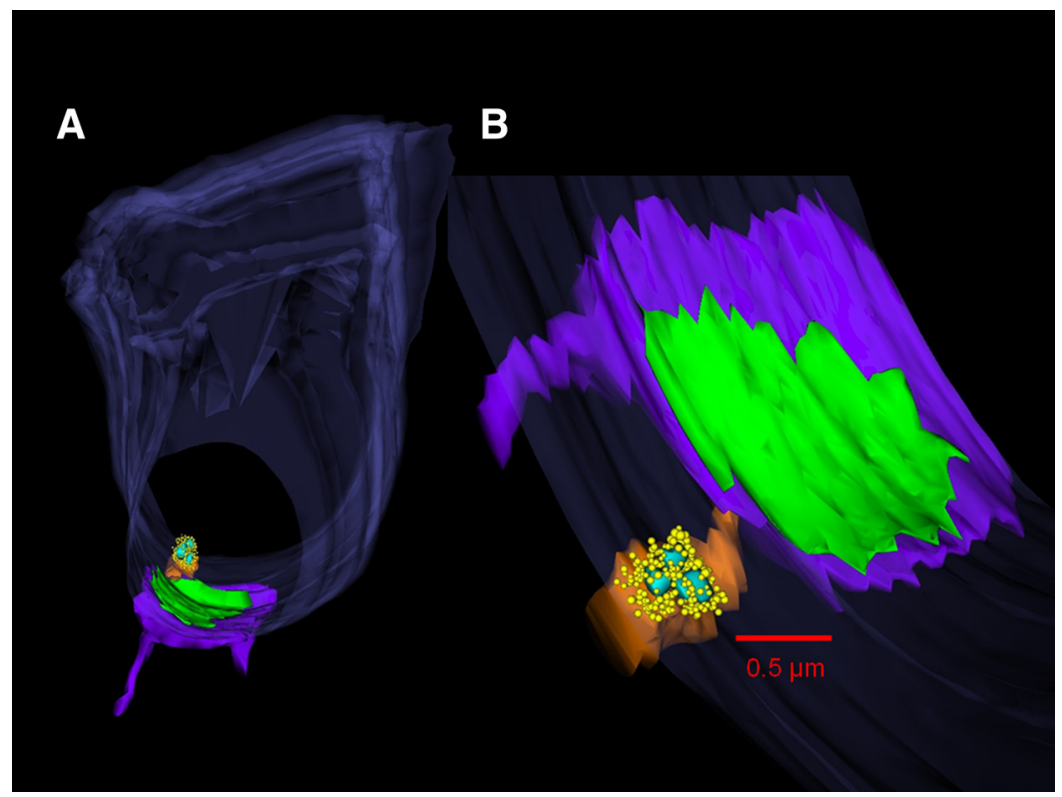

Figure 6. Efferent and afferent synapses on chicken hair cells. A, The z-axis projection of a 3-D reconstruction from 56 serial sections. The hair cell outline is shown in blue-gray, the efferent terminal in purple, the postsynaptic cistern in green, the afferent terminal in umber, the ribbon in turquoise, and synaptic vesicles in yellow. $\boldsymbol{B}$, Higher magnification of synaptic zone from $\boldsymbol{A}$, tilted forward $\sim 45^{\circ}$ from the plane of section in $\boldsymbol{A}$. Same color scheme.

Ryanodine has complex interactions with calcium-induced calcium release channels of endoplasmic stores (Pessah et al., 1987; Buck et al., 1992). At concentrations of 1-10 $\mu \mathrm{M}$, ryanodine promotes channel opening and calcium release. At 10-fold higher concentration, ryanodine inhibits calcium release. As observed in mammalian hair cells (Lioudyno et al., 2004), bath application of ryanodine at $100 \mu \mathrm{M}$ partially suppressed the ACh-evoked outward current at -40 $\mathrm{mV}$ in five cells (peak amplitude: control, $267 \pm 96 \mathrm{pA}$; in ryanodine, $99.0 \pm 45 \mathrm{pA}$; $p=0.015)$. This effect suggests that an internal calcium store participates in the prolonged response to ACh. More informative was the effect of a low, facilitating concentration of ryanodine. When ryanodine was applied at $1 \mu \mathrm{M}$, there was no effect on response amplitude at $-40 \mathrm{mV}$, but response duration (at half-amplitude) increased significantly in six cells (control, $1.83 \pm 0.32 \mathrm{~s}$; ryanodine, $2.57 \pm 0.51 \mathrm{~s}$; $p<0.01)$. Response duration returned to near control levels after removal of ryanodine $(2.00 \pm 0.71 \mathrm{~s})$. The effect of ryanodine $(1 \mu \mathrm{M})$ was still greater on ACh-evoked tail currents (Fig. 3A). Ryanodine had its largest effects on tail current duration at -20 or $0 \mathrm{mV}$ (Fig. $3 B$ ), where there was a twofold to fourfold increase in half-amplitude duration compared with the control. At positive membrane potentials, where calcium influx is reduced, ryanodine had little effect, so that tail current duration did not differ significantly from control values, as also observed at $-60 \mathrm{mV}$ where voltage-gated calcium channels are closed.

A second test of the activity of the cistern used the SERCA inhibitor $t$-BHQ, which reduces calcium uptake into endoplasmic stores (Verkhratsky, 2005). At 25 $\mu \mathrm{M}, t$-BHQ reduced the ACh-evoked current amplitude at $-40 \mathrm{mV}$ (Fig. $3 \mathrm{C}$ ) from $427 \pm 201$ to $132 \pm 82 \mathrm{pA}$ (repeatedmeasures ANOVA, $p<0.001 ; n=8$ ). The effect of $t$-BHQ on peak amplitude was partially reversible. After washing, the amplitude of the ACh response recovered to $295 \pm 88 \mathrm{pA}$.

While response amplitude showed some recovery, response duration remained reduced for many minutes after $t$-BHQ removal (Fig. 3C). Consequently, SERCA inhibition had a long-lasting effect on the extended tail currents seen at -20 and 0 $\mathrm{mV}$, eliminating the delayed component and leaving an exponentially declining current like those seen at positive membrane potentials (Fig. 3D). In four cells, the half-amplitude duration at $0 \mathrm{mV}$ of $704 \pm 558 \mathrm{~ms}$ in controls was reduced to $108 \pm 252 \mathrm{~ms}$ in $t$-BHQ. The residual tail currents were well fit with single exponentials, with an average decay constant of $83 \pm 132 \mathrm{~ms}$. This effect of SERCA inhibition is contrary to that observed if voltage-gated calcium diffuses directly to activate SK channels, since reduced endoplasmic uptake increases SK gating (Tucker and Fettiplace, 1996). Instead, the reduction of SK gating observed presently is consistent with the model whereby calcium reaches SK channels 
A

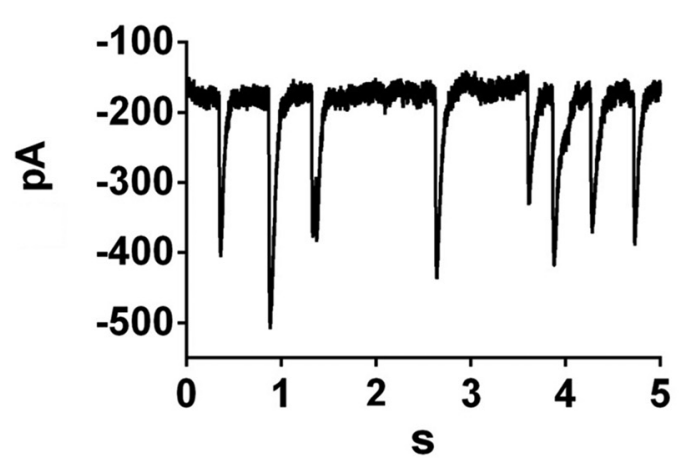

C

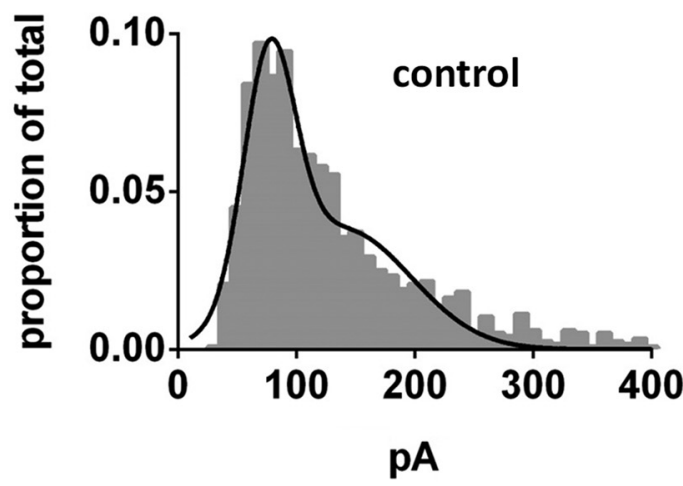

B

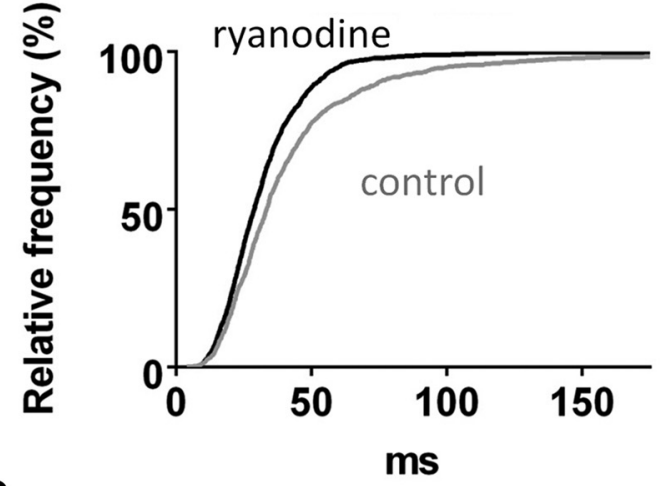

D

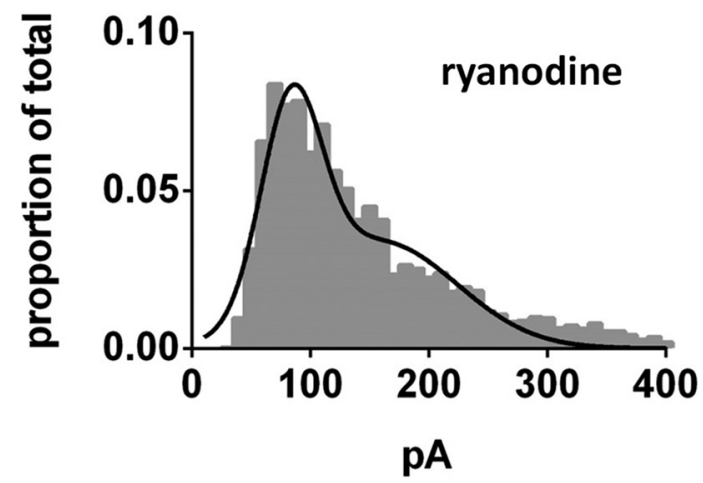

Figure 7. IPSCs in hair cells. $\boldsymbol{A}$, Voltage-clamp recording of inward currents at $-80 \mathrm{mV}$. Steady inward current of $\sim 150 \mathrm{pA}$ due to $40 \mathrm{~mm}$ potassium saline used to stimulate efferent release is shown. $\boldsymbol{B}$, Cumulative fraction plot (as a percentage of total counts) of synaptic current decay time constants ( $n=1159)$ pooled from eight hair cells in normal saline solution (gray) and faster synaptic decay time constants $(n=2450)$ pooled from seven cells exposed to $1 \mu$ m ryanodine (black). C, Amplitude histogram for pooled synaptic currents from control cells, normalized to the proportion of total counts. The solid line is the best-fit sum for two Gaussians centered at 77 and 139 pA. D, Amplitude histogram for pooled synaptic currents from ryanodine-exposed cells normalized to the proportion of total counts. The solid line is the best fit for a sum of two Gaussians centered at 84 and 158 pA.

principally through the mediation of an intracellular store, presumably the postsynaptic cistern.

\section{Postsynaptic cisterns in chicken hair cells}

As for efferent synapses on hair cells in other species, those on chicken hair cells include a near-membrane cistern that could serve as a fixed calcium buffer or store. The dimensions of postsynaptic cisterns in short chicken hair cells (analogous to cochlear outer hair cells) were determined with serial section electron microscopy. Serial section electron micrographs were collected from nine short hair cells (average $z$-axis depth, $4.3 \mu \mathrm{m}$; range $1-10 \mu \mathrm{m}$ ) to quantify the dimensions and disposition of the postsynaptic cisterns. The chosen cells were located in the abneural half of the papilla near the midpoint of its length, and had the expanded cuticular surface and abbreviated somatic length typical of this cell type. Tracings made on each section were used for 3-D reconstructions of the hair cell, efferent and cisternal membranes, the cytoplasmic space between the cistern and hair cell plasma membrane, and vesicle clusters in the efferent terminals.

Usually, one efferent terminal contacted the basal surface of each short hair cell and was aligned with a near-membrane cistern in the postsynaptic hair cell (Fig. $4 A, B$ ). Efferent terminal contacts with the hair cell ranged up to $5 \mu \mathrm{m}$ in maximal extent. The cisterns were significantly smaller than the terminal contact (Fig. $4 D$ ), corresponding to $\sim 50 \%$ of the contact area of the efferent terminal as projected through the $z$-axis $(56 \pm 16 \%, n=$
9). The cistern lay in close proximity to the plasma membrane (Fig. $4 C)$ at an average distance of $19 \pm 6 \mathrm{~nm}(n=9)$, thereby defining a restricted diffusion space for calcium acting on SK channels at the plasma membrane. The cisterns were flattened sacs, with an average luminal width of $33 \pm 3 \mathrm{~nm}(n=9)$, which was nearly twice that of the underlying cytoplasmic gap. The volume ratio of lumen to underlying cytoplasmic space for these nine synapses was $1.87 \pm 0.5$. These measurements illustrate that the cistern delimits a restricted diffusion space for calcium entering through open hair cell AChRs, but could also serve as a calcium store of modest capacity.

Since the efferent terminals cover substantially more of the plasma membrane of the hair cell than does the cistern, it was of interest to ask whether transmitter release occurs throughout the entire terminal contact area or is restricted to the region of the cistern. To this end, the disposition of synaptic vesicles was examined in efferent terminals on nine hair cells. Small clusters of vesicles focused on the plasma membrane (Fig. $5 \mathrm{~A}$, white arrows) were identified as putative active zones for transmitter release, and their location was mapped in 3-D reconstructions of the entire synaptic contact (Fig. 5B). A cumulative fraction plot of the distance between active zones and postsynaptic cisterns pooled from nine synapses shows that the great majority (470 of 517) lay within $100 \mathrm{~nm}$ (i.e., essentially opposite the cistern), with only few vesicle clusters scattered to the periphery of some synapses. 

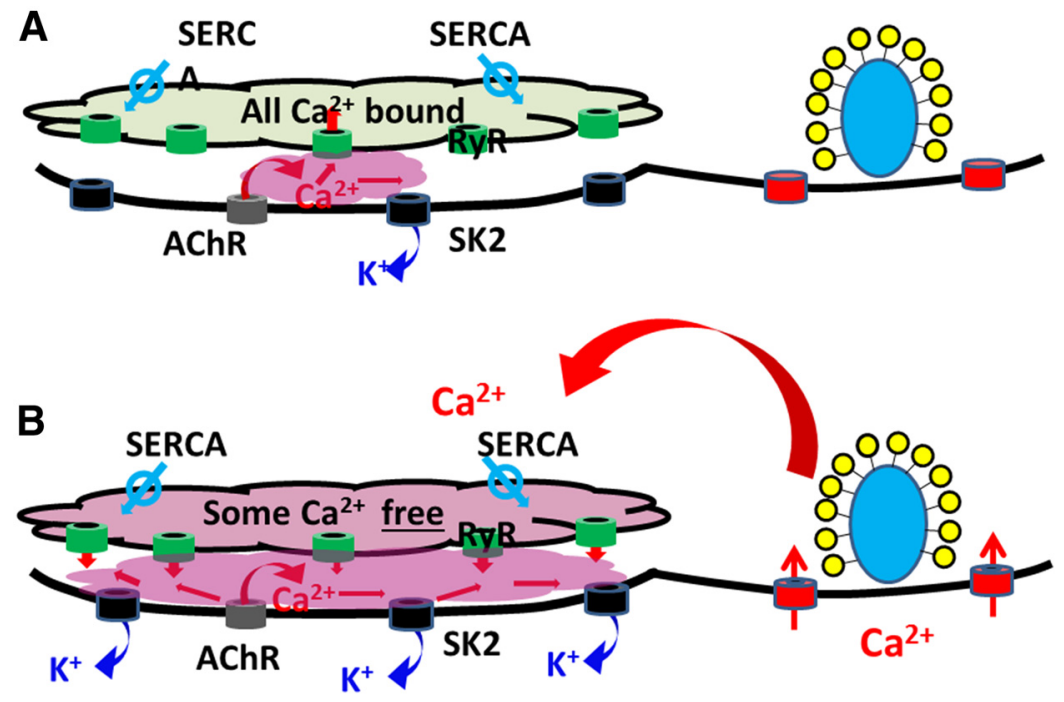

Figure 8. Postulated functions for the synaptic cistern [modified with permission from Fuchs (2014)]. $\boldsymbol{A}$, Under normal operating conditions (low levels of efferent or hair cell activity), calcium influx through hair cell nicotinic AChRs (gray) is rapidly absorbed by the synaptic cistern - perhaps through calcium-gated calcium channels such as the ryanodine receptor (RyR; green channels). B, Calcium entering through voltage-gated calcium influx at nearby ribbons is pumped into the cistern by SERCA. Free calcium in the loaded cistern slows the uptake of efferent calcium, and contributes calcium-induced calcium release that amplifies and extends the activation of SK channels (black channels). Note that this schematic shows only that portion of the membrane involving hair cell synaptic structures. It remains to be determined whether ACh receptors or SK channels also exist elsewhere.

In six of the cells examined, afferent (ribbon) synapses were observed in close proximity to the efferent contact (Fig. 6). These included one or more dense bodies and surrounding clouds of synaptic vesicles. Voltage-gated calcium channels are correlated with these afferent active zones (Martinez-Dunst et al., 1997). The nearest edge of the efferent cistern was less than $1 \mu \mathrm{m}$ from the ribbon on average $(411 \pm 495 \mathrm{~nm}, n=6)$.

\section{Efferent synaptic currents}

The preceding tail current measurements were obtained from relatively long-lasting responses to extrinsic (puffer) application of ACh. Do hair cell calcium stores influence the much briefer synaptic currents produced by efferent release of ACh? This question was addressed using a high-potassium $(40 \mathrm{mM})$ saline solution to depolarize efferent terminals and cause randomly timed transmitter release onto hair cells. In high external potassium, these efferent synaptic currents were entirely inward at $-80 \mathrm{mV}$ (Fig. 7A). In eight cells, potassium-evoked efferent synaptic currents had an average amplitude of $-124 \pm 74 \mathrm{pA}$. Single exponential fits to the decay time provided an average time constant of $42 \pm 35 \mathrm{~ms}$. In seven hair cells treated with $1 \mu \mathrm{M}$ ryanodine, the synaptic events were significantly briefer (mean decay time, $32 \pm$ $18 \mathrm{~ms} ; p<0.001$ compared with control). Cumulative fraction plots showed fewer long-lasting events in $1 \mu \mathrm{M}$ ryanodine (Fig. $7 B)$. Synaptic event amplitudes also were significantly larger on average in cells treated with ryanodine $(-149 \pm 92 \mathrm{pA} ; p<0.001$ compared with control). In the presence of ryanodine, the peaks of the amplitude distribution were shifted to slightly larger values, but also displayed fewer smaller events and an excess of large events not predicted by a best fit of two Gaussian distributions (Fig. $7 C, D$ ). Ryanodine may be acting on presynaptic calcium stores to increase the probability of transmitter release.

\section{Discussion}

Efferent release of ACh inhibits vertebrate hair cells by the activation of calcium-dependent potassium channels. The voltage dependence of ACh-evoked potassium tail currents reported here is consistent with the model whereby entry through ionotropic AChRs is the principal source of postsynaptic calcium (Martin and Fuchs, 1992; Evans, 1996; Oliver et al., 2000). Delayed voltage steps to alter the driving force showed that calcium influx through hair cell AChRs is necessary and sufficient to activate postsynaptic SK channels for tens of milliseconds-as occurs during the quantal release of ACh from the efferent terminal. That is, calcium reaches a sufficiently high concentration in the subcisternal cytoplasm (between the cistern and the postsynaptic plasma membrane) to activate SK channels, but then is rapidly removed when calcium influx ceases. Over this "synaptic time course," the cistern serves as a diffusion barrier and calcium sink (Fig. $8 A$ ).

The effects of drugs acting on calcium stores suggest, however, that the role of the cistern changes during prolonged activity and calcium loading (Sridhar et al., 1997; Evans et al., 2000; Lioudyno et al., 2004; Lipovsek et al., 2012). The efficacy of the cistern as a calcium sink will depend on the driving force between the subcisternal cytoplasm and the cisternal lumen. If free cisternal calcium rises (e.g., due to loading by voltage-gated influx), uptake will slow, or potentially reverse to release (Fig. 8B). This would explain the contribution of a voltage-gated calcium current to the enhanced ACh-evoked SK currents. Maximal voltage-gated calcium influx near $0 \mathrm{mV}$ contributed to SK gating within 100-200 ms under the conditions of the present experiments. This delayed contribution to SK channel gating is not due to the saturation of a diffusible cytoplasmic buffer $(5 \mathrm{mM}$ EGTA in these recordings), since the voltage step on its own was ineffective at activating SK current, but rather is relayed through a ryanodine-sensitive calcium store, presumably the postsynaptic cistern. Thus, under conditions that saturate the binding capacity of the cistern, calcium release contributes to ACh-evoked SK current activation. Compounds that alter store loading (inhibitors of $\mathrm{Ca}$ ATPase pumps) or the gating dynamics of endoplasmic calcium channels (ryanodine) influence the extent and time course of SK currents during longer-lasting inhibition. The present experiments demonstrate this effect using voltage-gated calcium influx to load the synaptic cistern. Presumably, such an effect could occur as well during long-lasting activation of ACh receptors.

Together, these results provide a unified hypothesis for calcium regulation at the efferent synapse of the hair cell. Calciuminduced calcium release mediated by ryanodine receptors modulates the magnitude of ACh-evoked SK current during periods of prolonged calcium influx, whether through AChRs or other sources. However, during low-level efferent activity, the cistern is an efficient calcium sink, and the time course of SK current is determined by the mean open time of the SK channels, since the synaptic calcium load is quickly absorbed into the cistern. What is the route for calcium absorption into the cistern? One possibility is that cisternal ryanodine receptors (calciuminduced calcium channels) are opened during efferent gating of calcium influx. The locally high concentration in the subcisternal space will not only open ryanodine receptors, but also will drive 
calcium into the cistern-as long as intracisternal calcium is largely bound. The effect of ryanodine on synaptic currents supports this interpretation. The time course of synaptic currents produced by stochastic release of ACh from efferent terminals was briefer in the presence of ryanodine, as though the subcisternal calcium was more rapidly absorbed. Note that these measurements were made at $-80 \mathrm{mV}$, where voltage-gated calcium channels are closed and so did not help to load the cistern. However, when cisternal buffering is saturated, as by the uptake of voltage-gated calcium influx, synaptic calcium loads will be longer lasting and will spread further. The propagation of calcium release will be enhanced by ryanodine, which alters the open probability of calcium-induced calcium release channels. It will be of interest to determine the role of postsynaptic calcium stores on electrically evoked efferent responses while membrane potential and timing are altered.

These proposed interactions all depend on the magnitude of various calcium sources and buffers, and the activity of calcium pumps and transporters. The present experiments were conducted on hair cells of late embryonic chickens, at a time when sensory hair cells and acoustic responses are essentially mature (Fuchs and Sokolowski, 1990; Jones et al., 2006). Nonetheless, similar studies in adult birds, as well as in hair cells from other species, are needed to determine the generality of these results. In addition, the present work was conducted at $21-23^{\circ} \mathrm{C}$, where the activity of channels, enzymes, and transporters are certainly different from in vivo conditions $\left(\sim 40^{\circ} \mathrm{C}\right.$ in chickens). In particular, the voltage-gated calcium current will be larger at body temperature (Grant and Fuchs, 2008), which could confer more influence over nearby efferent synapses. Nonetheless, even with these caveats, the present study shows that voltage-gated calcium influx can influence the cholinergic response of the hair cell, and that influence could be greater at body temperature in older hair cells.

The critical issue is the size of the cisterns relative to calcium influx. In this respect, it is of interest to consider how these interactions may occur in hair cells with different ratios of afferent and efferent innervation. Chicken short hair cells, like mammalian outer hair cells, have predominantly efferent synapses and cisterns, and very few afferent ribbons (Fischer, 1992; MartinezDunst et al., 1997). Consequently, the impact of voltage-gated calcium influx on efferent function is relatively modest. In contrast, voltage-gated calcium influx can activate the SK current directly, and this effect was enhanced by SERCA inhibition in turtle hair cells (Tucker and Fettiplace, 1996). Turtle hair cells have many ribbon synapses and fewer small efferent synapses and cisterns (Sneary, 1988). Similarly, large voltage-gated calcium influx can activate SK channels associated with efferent synapses in immature inner hair cells (Marcotti et al., 2004; Kong et al., 2008). The possibility of afferent and efferent cross talk could be of particular significance during the functional maturation of cochlear inner hair cells where calcium- and nitric oxidedependent retrograde facilitation alters the strength of efferent transmission (Kong et al., 2013). Activity-dependent calcium signaling could be the medium that determines synaptic rearrangements during development (Johnson et al., 2013) and in the aged cochlea (Lauer et al., 2012).

The conclusions arrived at here may apply to other cell types as well. Spinal motor neurons have "C-synapses," which involve postsynaptic cisterns associated with cholinergic contacts (Yamamoto et al., 1991; Nagy et al., 1993), and voltage-gated calcium channels and calcium-sensitive potassium channels cluster at hypolemmal cisterns in cerebellar Purkinje cells (Kaufmann et al., 2009; Indriati et al., 2013). It will be of interest to learn whether these near-membrane cisterns segregate calcium, as is proposed here.

Synaptic cisterns seem to be an obligatory feature of efferent contacts on vertebrate hair cells. Cisterns in mouse outer hair cells are generally similar to those described here, with the exception of tighter spacing of the cisternal lumen and underlying cytoplasmic gap (Fuchs et al., 2014). Also, the ratio of the cistern to efferent terminal appositional area is nearly 1:1 on mouse outer hair cells, rather than the 1:2 ratio observed in chicken hair cells. The functional significance of these structural differences remains to be determined but may relate to the higher calcium permeability of mammalian $\alpha 9 \alpha 10$ AChRs compared with those of chicken hair cells (Lipovsek et al., 2012). An appealing suggestion is that more extensive cisterns in mammalian hair cells better segregate the higher levels of calcium flux occurring at those synapses. In turn, such locally high calcium loads will more effectively gate the lower-calcium affinity BK channels that participate in cholinergic inhibition of mammalian outer hair cells (Wersinger et al., 2010).

Finally, the present work provides a cautionary tale regarding studies of store-dependent cellular function. For 2 decades, the weight of experimental evidence suggested a model whereby cholinergic inhibition of hair cells required release from calcium stores to activate calcium-dependent potassium channels as well as other hypothesized downstream effectors. While such interactions remain possible during prolonged activation of AChRs or other calcium sources, the present data and some previous work (Martin and Fuchs, 1992; Evans, 1996; Oliver et al., 2000) make a compelling case that influx through hair cell AChRs is necessary and sufficient to gate calcium-activated potassium channels to inhibit the hair cell. The synaptic cistern serves primarily to segregate, not to generate, calcium signals during low-level synaptic activity.

\section{References}

Art JJ, Fettiplace R (1984) Efferent desensitization of auditory nerve fibre responses in the cochlea of the turtle Pseudemys scripta elegans. J Physiol 356:507-523. Medline

Art JJ, Crawford AC, Fettiplace R, Fuchs PA (1982) Efferent regulation of hair cells in the turtle cochlea. Proc R Soc London B Biol Sci 216:377-384. CrossRef Medline

Blanchet C, Eróstegui C, Sugasawa M, Dulon D (1996) Acetylcholineinduced potassium current of guinea pig outer hair cells: its dependence on a calcium influx through nicotinic-like receptors. J Neurosci 16:25742584. Medline

Buck E, Zimanyi I, Abramson JJ, Pessah IN (1992) Ryanodine stabilizes multiple conformational states of the skeletal muscle calcium release channel. J Biol Chem 267:23560-23567. Medline

Dallos P, He DZ, Lin X, Sziklai I, Mehta S, Evans BN (1997) Acetylcholine, outer hair cell electromotility, and the cochlear amplifier. J Neurosci 17: 2212-2226. Medline

Dulon D, Lenoir M (1996) Cholinergic responses in developing outer hair cells of the rat cochlea. Eur J Neurosci 8:1945-1952. CrossRef Medline

Dulon D, Luo L, Zhang C, Ryan AF (1998) Expression of small-conductance calcium-activated potassium channels (SK) in outer hair cells of the rat cochlea. Eur J Neurosci 10:907-915. CrossRef Medline

Elgoyhen AB, Johnson DS, Boulter J, Vetter DE, Heinemann S (1994) Alpha 9: an acetylcholine receptor with novel pharmacological properties expressed in rat cochlear hair cells. Cell 79:705-715. CrossRef Medline

Elgoyhen AB, Vetter DE, Katz E, Rothlin CV, Heinemann SF, Boulter J (2001) alpha10: a determinant of nicotinic cholinergic receptor function in mammalian vestibular and cochlear mechanosensory hair cells. Proc Natl Acad Sci U S A 98:3501-3506. CrossRef Medline

Evans MG (1996) Acetylcholine activates two currents in guinea-pig outer hair cells. J Physiol 491:563-578. Medline

Evans MG, Lagostena L, Darbon P, Mammano F (2000) Cholinergic control of membrane conductance and intracellular free $\mathrm{Ca} 2+$ in outer hair cells of the guinea pig cochlea. Cell Calcium 28:195-203. CrossRef Medline

Fiala JC (2005) Reconstruct: a free editor for serial section microscopy. J Microsc 218:52-61. CrossRef Medline 
Fischer FP (1992) Quantitative analysis of the innervation of the chicken basilar papilla. Hear Res 61:167-178. CrossRef Medline

Flock A, Russell I (1973) Efferent nerve fibres: postsynaptic action on hair cells. Nat New Biol 243:89-91. CrossRef Medline

Fuchs PA (2014) A "calcium capacitor" shapes cholinergic inhibition of cochlear hair cells. J Physiol 592:3393-3401. CrossRef Medline

Fuchs PA, Murrow BW (1992a) Cholinergic inhibition of short (outer) hair cells of the chick's cochlea. J Neurosci 12:800-809. Medline

Fuchs PA, Murrow BW (1992b) A novel cholinergic receptor mediates inhibition of chick cochlear hair cells. Proc Biol Sci 248:35-40. CrossRef Medline

Fuchs PA, Sokolowski BH (1990) The acquisition during development of Ca-activated potassium currents by cochlear hair cells of the chick. Proc Biol Sci 241:122-126. CrossRef Medline

Fuchs PA, Lehar M, Hiel H (2014) Ultrastructure of cisternal synapses on outer hair cells of the mouse cochlea. J Comp Neurol 522:717-729. CrossRef Medline

Grant L, Fuchs P (2008) Calcium, calmodulin-dependent inactivation of calcium channels in inner hair cells of the rat cochlea. J Neurophysiol 99:2183-2193. CrossRef Medline

Gulley RL, Reese TS (1977) Freeze-fracture studies on the synapses in the organ of Corti. J Comp Neurol 171:517-543. CrossRef Medline

Indriati DW, Kamasawa N, Matsui K, Meredith AL, Watanabe M, Shigemoto $\mathrm{R}$ (2013) Quantitative localization of $\mathrm{Ca}_{\mathrm{v}} 2.1$ (P/Q-type) voltagedependent calcium channels in Purkinje cells: somatodendritic gradient and distinct somatic coclustering with calcium-activated potassium channels. J Neurosci 33:3668-3678. CrossRef Medline

Johnson SL, Wedemeyer C, Vetter DE, Adachi R, Holley MC, Elgoyhen AB, Marcotti W (2013) Cholinergic efferent synaptic transmission regulates the maturation of auditory hair cell ribbon synapses. Open Biol 3:130163. CrossRef Medline

Jones TA, Jones SM, Paggett KC (2006) Emergence of hearing in the chicken embryo. J Neurophysiol 96:128-141. CrossRef Medline

Kakehata S, Nakagawa T, Takasaka T, Akaike N (1993) Cellular mechanism of acetylcholine-induced response in dissociated outer hair cells of guinea-pig cochlea. J Physiol 463:227-244. Medline

Kaufmann WA, Ferraguti F, Fukazawa Y, Kasugai Y, Shigemoto R, Laake P, Sexton JA, Ruth P, Wietzorrek G, Knaus HG, Storm JF, Ottersen OP (2009) Large-conductance calcium-activated potassium channels in Purkinje cell plasma membranes are clustered at sites of hypolemmal microdomains. J Comp Neurol 515:215-230. CrossRef Medline

Kong JH, Adelman JP, Fuchs PA (2008) Expression of the SK2 calciumactivated potassium channel is required for cholinergic function in mouse cochlear hair cells. J Physiol 586:5471-5485. CrossRef Medline

Kong JH, Zachary S, Rohmann KN, Fuchs PA (2013) Retrograde facilitation of efferent synapses on cochlear hair cells. J Assoc Res Otolaryngol 14:17-27. CrossRef Medline

Lauer AM, Fuchs PA, Ryugo DK, Francis HW (2012) Efferent synapses return to inner hair cells in the aging cochlea. Neurobiol Aging 33:2892-2902. CrossRef Medline

Lee S, Briklin O, Hiel H, Fuchs P (2007) Calcium-dependent inactivation of calcium channels in cochlear hair cells of the chicken. J Physiol 583:909922. CrossRef Medline

Lioudyno M, Hiel H, Kong JH, Katz E, Waldman E, Parameshwaran-Iyer S, Glowatzki E, Fuchs PA (2004) A "synaptoplasmic cistern" mediates rapid inhibition of cochlear hair cells. J Neurosci 24:11160-11164. CrossRef Medline

Lipovsek M, Im GJ, Franchini LF, Pisciottano F, Katz E, Fuchs PA, Elgoyhen AB (2012) Phylogenetic differences in calcium permeability of the auditory hair cell cholinergic nicotinic receptor. Proc Natl Acad Sci U S A 109:4308-4313. CrossRef Medline

Marcotti W, Johnson SL, Kros CJ (2004) A transiently expressed SK current sustains and modulates action potential activity in immature mouse inner hair cells. J Physiol 560:691-708. CrossRef Medline

Martin AR, Fuchs PA (1992) The dependence of calcium-activated potassium currents on membrane potential. Proc Biol Sci 250:71-76. CrossRef Medline

Martinez-Dunst C, Michaels RL, Fuchs PA (1997) Release sites and calcium channels in hair cells of the chick's cochlea. J Neurosci 17:9133-9144. Medline
Matthews TM, Duncan RK, Zidanic M, Michael TH, Fuchs PA (2005) Cloning and characterization of SK2 channel from chicken short hair cells. J Comp Physiol A Neuroethol Sens Neural Behav Physiol 191:491-503. CrossRef Medline

McNiven AI, Yuhas WA, Fuchs PA (1996) Ionic dependence and agonist preference of an acetylcholine receptor in hair cells. Aud Neurosci 2:63-77.

Murrow BW (1994) Position-dependent expression of potassium currents by chick cochlear hair cells. J Physiol 480:247-259. Medline

Murrow BW, Fuchs PA (1990) Preferential expression of transient potassium current (IA) by "short" hair cells of the chick's cochlea. Proc Biol Sci 242:189-195. CrossRef Medline

Nagy JI, Yamamoto T, Jordan LM (1993) Evidence for the cholinergic nature of C-terminals associated with subsurface cisterns in alphamotoneurons of rat. Synapse 15:17-32. CrossRef Medline

Nenov AP, Norris C, Bobbin RP (1996) Acetylcholine response in guinea pig outer hair cells. II. Activation of a small conductance $\mathrm{Ca}(2+)$ activated K+ channel. Hear Res 101:149-172. CrossRef Medline

Ohmori H (1993) Efferent synapse mechanisms in chick hair cells. Prog Brain Res 97:7-11. CrossRef Medline

Oliver D, Klöcker N, Schuck J, Baukrowitz T, Ruppersberg JP, Fakler B (2000) Gating of $\mathrm{Ca} 2+$-activated $\mathrm{K}+$ channels controls fast inhibitory synaptic transmission at auditory outer hair cells. Neuron 26:595-601. CrossRef Medline

Pessah IN, Stambuk RA, Casida JE (1987) Ca2+-activated ryanodine binding: mechanisms of sensitivity and intensity modulation by $\mathrm{Mg} 2+$, caffeine, and adenine nucleotides. Mol Pharmacol 31:232-238. Medline

Saito K (1980) Fine structure of the sensory epithelium of the guinea pig organ of Corti: afferent and efferent synapses of hair cells. J Ultrastruct Res 71:222-232. CrossRef Medline

Shigemoto T, Ohmori H (1990) Muscarinic agonists and ATP increase the intracellular Ca2 + concentration in chick cochlear hair cells. J Physiol 420:127-148. Medline

Shigemoto T, Ohmori H (1991) Muscarinic receptor hyperpolarizes cochlear hair cells of chick by activating $\mathrm{Ca}(2+)$-activated $\mathrm{K}+$ channels. J Physiol 442:669-690. Medline

Smith CA, Sjöstrand FS (1961) A synaptic structure in the hair cells of the guinea pig cochlea. J Ultrastruct Res 5:182-192.

Sneary MG (1988) Auditory receptor of the red-eared turtle. II. Afferent and efferent synapses and innervation patterns. J Comp Neurol 276:588-606. Medline

Sridhar TS, Brown MC, Sewell WF (1997) Unique postsynaptic signaling at the hair cell efferent synapse permits calcium to evoke changes on two time scales. J Neurosci 17:428-437. Medline

Sugai T, Yano J, Sugitani M, Ooyama H (1992) Actions of cholinergic agonists and antagonists on the efferent synapse in the frog sacculus. Hear Res 61:56-64. CrossRef Medline

Tan X, Beurg M, Hackney C, Mahendrasingam S, Fettiplace R (2013) Electrical tuning and transduction in short hair cells of the chicken auditory papilla. J Neurophysiol 109:2007-2020. CrossRef Medline

Tucker TR, Fettiplace R (1996) Monitoring calcium in turtle hair cells with a calcium-activated potassium channel. J Physiol 494:613-626. Medline

Verkhratsky A (2005) Physiology and pathophysiology of the calcium store in the endoplasmic reticulum of neurons. Physiol Rev 85:201-279. CrossRef Medline

Wersinger E, McLean WJ, Fuchs PA, Pyott SJ (2010) BK channels mediate cholinergic inhibition of high frequency cochlear hair cells. PLoS One 5:e13836. CrossRef Medline

Wiederhold ML, Kiang NY (1970) Effects of electric stimulation of the crossed olivocochlear bundle on single auditory-nerve fibers in the cat. J Acoust Soc Am 48:950-965. CrossRef Medline

Winslow RL, Sachs MB (1987) Effect of electrical stimulation of the crossed olivocochlear bundle on auditory nerve response to tones in noise. J Neurophysiol 57:1002-1021. Medline

Yamamoto T, Hertzberg EL, Nagy JI (1991) Subsurface cisterns in alphamotoneurons of the rat and cat: immunohistochemical detection with antibodies against connexin32. Synapse 8:119-136. CrossRef Medline

Zidanic M (2002) Cholinergic innervation of the chick basilar papilla. J Comp Neurol 445:159-175. CrossRef Medline

Zidanic M, Fuchs PA (1995) Kinetic analysis of barium currents in chick cochlear hair cells. Biophys J 68:1323-1336. CrossRef Medline 